\title{
3.2 Сприятливий інвестиційний клімат - важлива складова полегшення ведення бізнесу
}

Створення сприятливого інвестиційного клімату, зокрема у разі залучення зарубіжних інвестицій в сучасних умовах розвитку економіки України є одним 3 найважливіших чинників стабілізації економічної ситуації, зниження рівня «тінізації» економіки та економічної безпеки держави загалом. Загалом під інвестиційним кліматом розуміють сукупність політичних, соціальноекономічних, фінансових, організаційно-правових, природних чинників, властивих тій чи іншій країні, регіону, які визначають вибір інвесторів відносно місця, часу і форми вкладення коштів. Як свідчить світова практика, країни із постіндустріальною економікою, зокрема й Україна, не в змозі розвивати ії без залучення й ефективного використання інвестицій. Від їх якісних і кількісних характеристик залежать економічний потенціал країни, його ефективність, галузева та відтворювальна структура суспільного виробництва, спрямованість стратегій соціально-економічного розвитку економіки [50].

Закордонні фахівці в дослідженнях економічного змісту інвестицій наголошують на таких чинниках: а) приріст функціонуючого капіталу; б) одержання додаткового доходу; в) відмова від частини поточного споживання на користь очікуваного розширення споживання в майбутньому.

Аналіз сучасної зарубіжної і вітчизняної наукової літератури дозволив сформулювати декілька підходів до визначення сутності поняття «інвестиції».

За «цільовим» підходом критерієм віднесення тих чи інших вкладень до інвестицій є мета їх здійснення. Ряд іноземних економістів [51, с. 10; 52, с. 173] розуміють під інвестиціями будь-який інструмент вкладення грошей з метою збереження чи примноження їх вартості, отримання доходу або досягнення приросту капіталу, або для того й іншого.

У макроекономічному аспекті інвестиційна діяльність $є$ процесом формування майбутнього економіки країни. Чим більші обсяги інвестицій сьогодні, тим більшими будуть обсяги валового внутрішнього продукту країни завтра. 
Інвестиціями підприємства, як вважає I.О. Бланк [53, с. 38], є вкладення капіталу у всіх його формах в різні об'єкти (інструменти) його господарської діяльності з метою отримання прибутку, досягнення економічного ефекту. Практично такої ж точки зору дотримуються й інші автори [54, с. 157; 55, с. 166].

Однак метою інвестування може бути досягнення не тільки прибутку, а й соціального ефекту (якщо об’єкт інвестування не є суб'єктом підприємницької діяльності).

Згідно $з$ другим підходом критерієм вкладення капіталу як інвестицій $є$ строки їх використання. Багато вітчизняних i зарубіжних економістів розглядають інвестиції як довгострокове вкладання капіталу в різні сфери i галузі економіки, інфраструктуру, соціальні програми, охорону навколишнього природного середовища як всередині країни, так і за кордоном з метою розвитку виробництва, соціальної сфери, підприємництва, одержання прибутку [56, с. 8 , c. 345].

Натомість в літературі зустрічаються терміни як «довгострокові» так $\mathrm{i}$ «короткострокові інвестиції» [58, с. 13; 59, с. 12], що має право на життя, особливо в умовах фінансово-економічних криз, коли необхідним стає мінімізація термінів окупності інвестицій.

За третім підходом інвестиції трактуються як використання капіталу через певний час на противагу поточному споживанню. Прихильники такого підходу, зокрема У. Шарп із співавторами, визначали термін «інвестиція» як відмову від певної цінності в поточному періоді з метою отримання цінності в майбутньому, але в зростаючих розмірах [60, с. 29].

Однією з найголовніших складових теорії Дж. Кейнса були інвестиції. Він сформулював правило, яке зводиться до того, що «в будь-якому новому прирості сукупних доходів частка заощаджень зростає випереджальними темпами стосовно частки, яка споживається, а отже, забезпечується основа майбутніх інвестицій» [61, с. 116]. Французький економіст П. Массе також вважав, що найзагальніше визначення інвестиції, яке можна дати актові вкладення капіталу, зводиться до наступного: «інвестування $є$ актом обміну капіталу на задоволення 
в майбутньому інвестиційними благами». Такої позиції дотримувалися й інші американські економісти [62, с. 13].

Проте, слушні за своєю сутністю, такі характеристики інвестицій не повною мірою розкривають цю складну економічну категорію.

Слід також погодитися 3 науковцями, що поняття «інвестиції» $\epsilon$ первинною категорією, яка лежить в основі побудови ієрархії решти категорій, що відображають відтворення основного та оборотного капіталу. 3 огляду на це, вважаємо, що інвестування - це процес акумуляції коштів у різній формі (гроші, акції, цінні папери, пайові внески, рухоме і нерухоме майно, авторські права тощо), перетворення їх в інвестиційні товари та ресурси, введення останніх у виробничу стадію і трансформація у перетворюючі інноваційні фактори ресурси, а далі у капітал.

Таке розуміння категорії інвестицій $є$ важливим теоретикометодологічним підгрунтям для аналізування стану й організації інвестиційних процесів, основних джерел інвестицій, умов перетворення їх у чинники ресурсів суспільного відтворення, стану й передумов формування повноцінного ринку інвестиційних товарів [50].

Загалом інвестиційний клімат визначається як сукупність політичних, економічних, юридичних, соціальних та інших факторів, що визначають у кінцевому рахунку ступінь ризику капіталовкладень і можливість їхнього ефективного використання [50]. Він формується під впливом незалежних від окремих суб'єктів господарювання та суттєво впливає на їх інвестиційну поведінку. Поняття інвестиційного клімату відрізняється складністю й комплексністю і може розглядатися на макро- і мікроекономічному рівні. На макроекономічному рівні воно містить у собі показники політичного (включаючи законодавство), економічного й соціального середовища для інвестицій. Для потенційних інвесторів в Україні у разі аналізування політичної ситуації вирішальну роль відіграють політика держави щодо іноземних інвестицій, імовірність націоналізації іноземного майна, участь країни в системах міжнародних договорів із різних питань, міцність державних 
інститутів, наступність політичної влади, ступінь державного втручання в економіку тощо [50].

В сучасній теорії та практиці інвестиційної діяльності існують різні підходи до оцінювання інвестиційного клімату, що, що розрізняються залежно від цілей дослідження, за кількістю аналізованих показників та їхніх якісних характеристик [50].

Універсальна методика оцінювання інвестиційного клімату, що охоплює максимальну кількість економічних характеристик, показників торгівлі, характеристик політичного клімату, законодавчого середовища для інвестицій (автори Б. Тойн, П. Уолтерс та ін.), дозволяє глибоко й усебічно оцінити ситуацію в країні на даний момент і судити про можливість іï розвитку. Для порівняльного аналізу інвестиційного клімату в державах Східної та Центральної Свропи, з урахуванням країн, що раніше входили до СРСР, використовуються спеціальні методики, де увага акцентується на темпах й перспективах реформ [50].

Методики бальної оцінки, основна перевага яких - можливість кількісного зіставлення основних характеристик інвестиційного клімату для різних країн і виділення остаточного показника, який враховує величини всіх складових i ранжування різних країн, служать критерієм їхньої привабливості для іноземних інвесторів.

На інвестиційному кліматі негативно позначаються не тільки прямі обмеження діяльності іноземних фірм, що містяться в законодавстві, але й нечіткість i, особливо, нестабільність законодавства приймаючої країни, оскільки ця нестабільність позбавляє інвестора можливості прогнозувати розвиток подій, що знижує рентабельність вкладень. Серед економічних параметрів основна увага в оцінці інвестиційного клімату приділяється загальному стану економіки, стану валютної, фінансової і кредитної систем, митному режиму, можливостям використання робочої сили (вартість робочої сили i ऑii співвідношення із середнім рівнем кваліфікації працівників i продуктивністю праці) [50]. 
Велику роль в оцінці соціального середовища для інвестицій відіграють показники ставлення до іноземних інвестицій у суспільстві, ступінь його розшарування, наявність чи відсутність згоди з основних питань економічного й соціального розвитку країни, рівень безробіття, можливість страйків.

На мікроекономічному рівні інвестиційний клімат проявляє себе через двосторонні відносини фірми-інвестора i конкретних державних органів, господарських суб'єктів-постачальників, покупців, банків, а також профспілок і трудових колективів приймаючої країни. На цьому рівні відбувається конкретизація узагальненої оцінки інвестиційного клімату в ході реальних економічних, юридичних, культурних контактів іноземної фірми з новим середовищем [50].

Макро- і мікрорівні інвестиційного клімату сприймаються інвесторами як єдине ціле, оскільки будь-які законодавчі зусилля уряду сформувати сприятливий інвестиційний клімат можуть блокуватися нормотворчістю місцевої влади, а зусилля на місцевому рівні щодо створення пільгового господарського режиму для іноземних інвестицій - найчастіше компенсують деякі вади загальноекономічного регулювання центрального уряду.

Використання нових методологічних підходів дає можливість характеризувати інвестиційний клімат як особливу підсистему в інституційній системі економіки, покликану створити передумови для найкращого використання суспільно-економічних відносин у розвитку $\mathrm{i}$ науковотехнологічному відновленні продуктивних сил суспільства через активну інвестиційну діяльність [50].

Не існує єдиного загальновизнаного переліку економічних показників, необхідних для характеристики інвестиційного клімату, їх набір залежить від форми інвестицій, ознак суб'єкта, терміну і умов інвестування. Категорія «інвестиційний клімат» об’єднує в собі соціально-економічні характеристики країни-одержувача 3 інтересами зарубіжних вкладників капіталу. Чим гірше інвестиційний клімат в країні, тим більш високим $є$ для інвестора підприємницький ризик, i, відповідно, вірогідність вступу зовнішніх капіталів буде меншою. Таким чином, стан інвестиційного клімату - не абстракція, він має 
своє кількісне вираження, яке для інвестора виражається в очікуваній прибутковості вкладень, а для країни, яка отримує інвестиції, - в реально отриманих зарубіжних інвестиційних ресурсах [50].

Для оцінювання інвестиційного клімату найчастіше використовуються так звані економічні індекси, які характеризують певні аспекти діяльності в тій чи іншій економічній системі країни: рівень конкурентоспроможності, прозорість (транспарентність) ринків, рівень економічної свободи чи корупції. Про наявність сприятливого або несприятливого інвестиційного клімату в країні часто роблять висновок за макроекономічною та монетарною політикою держави. Непрямими показниками можуть бути рейтинги сприятливості щодо ведення бізнесу (по відношенню до вітчизняних підприємців та інвесторів, іноземних інвесторів, з урахуванням податкового режиму, втручання держави в економіку та регулювання цін, конкурентоспроможності ринку, обмеження для іноземців, рівня корупції та свободи) [50].

Конкурентоспроможність країни, регіону, суб’єкта господарювання визначається двома головними чинниками: наявним ресурсним, інвестиційним потенціалом та ефективним його використанням; ефективною системою державного регулювання інвестиційних потоків. Україна має не дуже високий ресурсний та досить низький рівень інвестиційного потенціалу, тому в міжнародному рейтингу конкурентоспроможності не займає провідних позицій. Так, за результатами щорічного рейтингового дослідження Міжнародної фінансової корпорації, група Світового банку «Ведення бізнесу - 2018» та «Ведення бізнесу - 2020» за загальним рейтингом відбулось підвищення позицій України у 2020 році порівняно з 2018 роком. Так, Україна у 2020 році посіла 64 місце, у 2018 - 71 (табл. 1).

Таблиця 1. Рейтинг МФК щодо ведення бізнесу в Україні у 2020/2018 роках

\begin{tabular}{|c|c|c|c|c|c|}
\hline Рейтинг за категоріями & Роки & Нова Зеландія & Сінгапур & Данія & Україна \\
\hline \multirow{2}{*}{ Глобально } & 2018 & 1 & 2 & 3 & 71 \\
\hline & 2020 & 1 & 2 & 4 & 64 \\
\hline \multirow{2}{*}{ Реєстрація підприємств } & 2018 & 1 & 3 & 42 & 56 \\
\hline & 2020 & 1 & 4 & 45 & 61 \\
\hline \multirow{2}{*}{$\begin{array}{c}\text { Отримання дозволів на } \\
\text { будівництво }\end{array}$} & 2018 & 6 & 8 & 4 & 30 \\
\hline & 2020 & 7 & 5 & 4 & 20 \\
\hline Реєстрація власності & 2018 & 1 & 21 & 11 & 63 \\
\hline
\end{tabular}




\begin{tabular}{|c|c|c|c|c|c|}
\hline Рейтинг за категоріями & Роки & Нова Зеландія & Сінгапур & Данія & Україна \\
\hline \multirow{2}{*}{ Отримання кредитів } & 2020 & 2 & 21 & 11 & 61 \\
\hline \multirow{2}{*}{$\begin{array}{c}\text { Захист міноритарних } \\
\text { інвесторів }\end{array}$} & 2018 & 1 & 32 & 44 & 32 \\
\cline { 2 - 6 } & 2020 & 1 & 37 & 48 & 37 \\
\cline { 2 - 6 } Оподаткування & 2018 & 1 & 7 & 38 & 72 \\
\hline \multirow{2}{*}{ Міжнародна торгівля } & 2020 & 3 & 3 & 28 & 45 \\
\cline { 2 - 6 } & 2020 & 10 & 8 & 9 & 54 \\
\hline \multirow{2}{*}{ Забезпечення виконання } \\
контрактів & 2018 & 60 & 45 & 1 & 78 \\
\cline { 2 - 6 } & 2018 & 21 & 1 & 1 & 74 \\
\hline
\end{tabular}

Джерело *. Систематизовано, узагальнено та згруповано за даними [50, с. 14].

В цілому, можна констатувати, що наразі існує нагальна потреба в розробленні адекватних сучасним умовах заходів щодо покращення інвестиційного клімату, зниження рівня «тінізації» економіки й підвищення економічної безпеки держави загалом [64-69]. Проте загрозливим залишається рівень корупції. Вважається, що якщо річний ВВП на одного громадянина нижчий за 8 тис. дол. США, то така держава не може бути некорумпованою. В Україні ж за всіма підрахунками (враховуючи всі соціальні пільги та виплати) цей показник становив не більше 5 тис. дол. США. Тому досягнення хоча б нижньої межі дасть змогу зробити висновок про зменшення рівня корупції [50].

При цьому, слід зазначити, що покращення інвестиційного клімату може бути забезпечено за умови реалізації комплексу заходів, спрямованих, наряду 3 іншим, на створення умов полегшення ведення бізнесу, основним з яких є такі:

- створення сприятливого середовища для ведення бізнесу;

- забезпечення довгострокової фінансової стабільності;

- підвищення ефективності державного управління;

- розвиток конкуренції на внутрішньому товарному ринку [50]. 